Journal of Engineering and Applied Sciences 15 (7): 1692-1697, 2020

ISSN: 1816-949X

(c) Medwell Journals, 2020

\title{
The Sense of Syncretism in Bugis Architecture at the Traditional Houses of Towani To-Lotang Community
}

\author{
Aris Alimuddin, Shirly Wunas, Mimi Arifin and Ria Wikantari \\ Department of Engineering, Program in Architecture Faculty of Universitas Hasanuddin, \\ Makassar, Indonesia
}

\begin{abstract}
The syncretism of architecture is the process of achieving the balance by each human which includes the integration, intermixture or combination related to religious activities, traditions, cultural practices and adaptations to the environment such as a building that displays a form of syncretism values between architectural concepts that are implemented into buildings on macro and micro scales. This study aims to analyze the concept of the traditional home of To-lotang in the sense of syncretism through symbols and messages. This research is a qualitative research. The data collection method of this study uses purposive sampling with direct observation in-depth interviews, sketches and documentation. The object of this research is Towani To-Lotang traditional house units located in Sidrap district, South Sulawesi. The results shows that the meaning of syncretism in Towani To-Lotang's house has a unanimous philosophy symbolizing the unity and the messages behind the form and function of a traditional home of Towani To-Lotang symbolize the social solidarity.
\end{abstract}

Key words: Sense of syncretism, symbols and messages, Sidrap district, symbolize, sketches

\section{INTRODUCTION}

Although, the penetration of Islamic teachings has been being conducted for quite long in South Sulawesi, traditional beliefs (syncretism) still exist to most traditional Bugis society. The traditional beliefs that they adhere to are classified into two types: "esoteric syncretism" and "practical syncretism". What can be put into the category of esoteric syncretism is the teaching of the belief that originated in the early period of Islamization which was spread out through mostly oral texts (though some are written) by the followers of that belief such as those in nobility of Luwu or in the tradition of To-Lotang in Sidenreng. This belief is sometimes associated with sacred places such as those around Cerekang (Ussu') in Luwu' or bulu' Lowa in Amparita (Sidenreng). A number of esoteric texts which were very sacred by their adherents, contain teachings that combined Islamic Sufism with the concept of God (theology) and the concept of the pre-Islamic Bugis cosmology. Only few followers of this path or tarekat have seen the book which sometimes must not be read without performing rites and preparing certain offerings. Perlas, 2006. The practical syncretism is broad and is carried out openly in South Sulawesi, although, widely opposed by adherents of orthodox Islamic teachings. Practical syncretism does not have any particular conceptual rules. People can only draw conclusions about the underlying concepts by observing various "religious practices" of Bugis people, for example the life cycle rites, the rites relating to agriculture, house construction, boat construction and fishing as well as treatment rites. These practices actually are contrary to Islam now that they tend to treat entities spiritual entities (to-alusu) and mystical entities (to-tenrita) as intermediaries for relationships of humans with God. The implications of polytheism from these practices are not always realized by those who carry it out. Most of the adherents of the practical syncretism consider to-alusu' and to-tenrita as gods or the spirits of the ancestors and some others consider them as genie or mala'ika (angel). Eventually, Islamic teachings also recognize the existence of genies and angels, yet they are not to be worshiped. The remnants of the habit of worshiping ancestors were generally, accepted before the Islamization and now remain like offerings of rice at the rites of new homes construction and offerings of porridge at the celebration of 'Ashura but there are no more remnants of pre-Islamic practices in the funeral ceremony. However, visiting to the tombs of certain figures who are trusted as an intermediary between humans and God is still applied. That figures that they categorize, so such as mythical figures of kingdom founders, historical heroes, Sufis or figures considered by local people possessing extraordinary power. Based on the urgency mentioned above, the research question of the sense of Syncretism in Bugis architecture in the Traditional home of To-wani To lotang community in Sidrap regency, South Sulawesi is arranged as follows: 


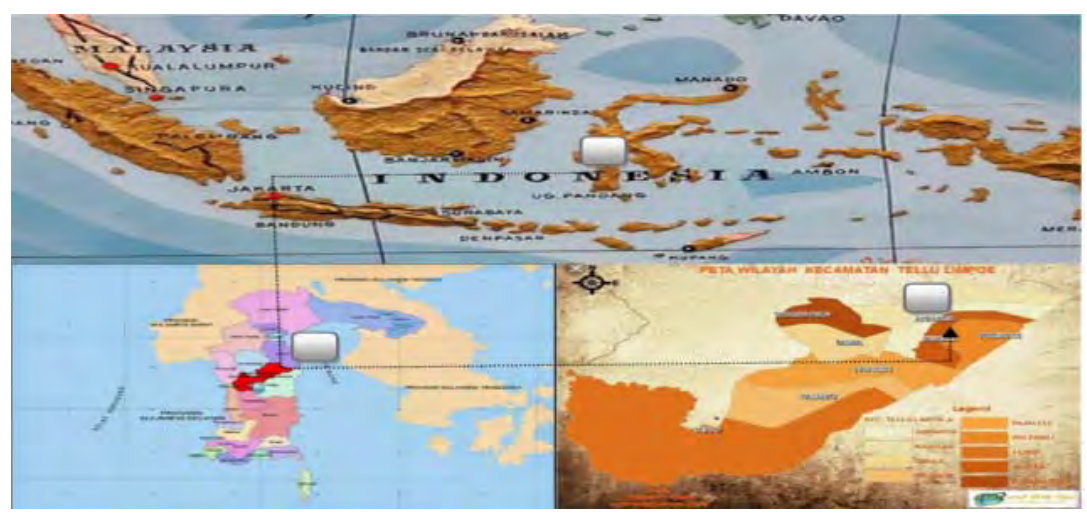

Fig. 1: The research location in Tellu Limpoe, Amparita, Sidrap regency South Sulawesi

- What do the symbols and messages of Towani tolotang traditional house architecture look like?

The purpose of this study is expected to be able to analyze the sense of Bugis architectural syncretism to symbols and messages in the house of Tolotang community in Sidrap regency, South Sulawesi.

\section{Literatur riview}

Research location: Amparita village is located in the South of Sidrap regency, $9 \mathrm{~km}$ from the Southern center of Sidenreng Rappang regency and it is $221 \mathrm{~km}$ from the capital city South Sulawesi. Amparita is in Tellu Limpoe district. Regional boundaries are as follows Fig. 1:

- The North is bordered by Arateng village

- The East is bordered by Teteaji village

- The South is bordered by Kelurahan Pajalele

- $\quad$ The West side is bordered by Toddang Pulu and Baula village. Administratively, the last two villages were the part Amparita village before the expansion of territory with an area $364.74 \mathrm{~km}^{2}$

- $\quad$ Piture maps

Hermeneutic interpretation approach: In understanding the meaning of architectural syncretism, the theoretical approach used was hermeneutic interpretation approach by Ricoeur (1981). The word hermeneutika or hermeneutik is the bahasa of hermeneutics in English. This last word is derived from the Greek verb hermeneuo which means "to express someone's thoughts in words". The verb also means "translate" and "Act as interpreters". All these three definitions actually intend to reveal that hermeneutics is an attempt to move away from something relatively dark to something brighter. In the first sense, hermeneuein can be understood as a kind of transition from something relatively abstract and dark such as thoughts to clear expressions in the form of language. Solidification of thoughts in language has been considered as an interpretation. In the second sense "translate", there is an attempt to distract ourselves from Foreign languages whose meaning is still dark into our own language whose meaning is clear. In the third sense, when someone is interpreting something, he passes an expression which is still obscure and leads to clearer ones the form of thought which is less clearly transformed into clearer forms of thought can be defined as interpreting. Budi Hardiman, (2015). Therefore, "hermeneutics" always deals with three internal elements in interpretation activities, namely: the sign, message or text that is the source or material in interpretation that is associated with the message carried by Hermes, intermediaries or interpreters (Hermes), the delivery of the message by the Intermediary in order to be understood and to reach the recipient (Faiz, 2002). According to Ricoeur (1981) hermeneutics is a way to understand texts which at the end of the process leads to the discovery of meaning or message. From the scheme, it appears that the meaning and message in hermeneutic interpretation are in the most extensive and far from the text (works of art as ontological facts) but it remains within the horizon emitted by the text. Hermeneutics, at the beginning of its development was recognized more as an exegesis movement among the church, then developed into a "philosophy of interpretation" developed by Schleiermacher. He is considered as "the Father of Modern Hermeneutics" because of standardizing hermeneutics becoming a common method of interpretation that is not limited to the holy books and literature. Then, Wilhelm Dilthey developed hermeneutics as a foundation for the science of humanity (Geisteswissenschaften). After that, Hans-Georg Gadamer developed hermeneutics to be a philosophical method, especially in his famous book "Truth and Method". Furthermore, hermeneutics was further developed by the philosophers such as Paul Ricoeur, Jurgen Habermas and Jacques Derrida. The development of this hermeneutics penetrated to various scientific studies and the science that is closely related to the study of hermeneutics is the science of history, philosophy, law, literature and science 
about humanity. Wachid (2006). From the history of hermeneutic, Paul Ricoeur (born 1913 in Valence, Southern France) who directed hermeneutics more into interpretation activities and understanding of text (textual exegesis). According to a professor of philosophy at the University of Nanterre (an extension of the Sorbonne University)" basically the whole philosophy is the interpretations on interpretations. "Paul Ricoeur agreed with Nietzsche that "Life itself is an interpretation. If there is plurality in meanings, interpretations are needed there. Paul ricoeur addresses the interpretation of "signs or symbols which is considered as text". What is meant in this case is "the interpretation of expressions of life that is determined linguistically". That is due to all life activities of humans dealing with language, even all forms of art displayed visually are interpreted by using language. "Humans are basically a language and language itself is the main requirement for human experience, "said Paul Ricoeur.

\section{MATERIALS AND METHODS}

Therefore, hermeneutics is a new way of 'getting along' with language. Therefore, the interpreter has the duty to unravel the entire life chain and latent history in language. In Paul Ricoeur's perspective through his book the Interpretation Theory: Discourse and the Surplus of Meaning (1976), there are three steps of understanding, starting from "appreciation of symbols" to the level of ideas about "thinking from symbols" and these are the following details:

- Symbolic steps or understanding of symbols

- Giving meaning by symbols and careful "digging” or meaning

- Philosophical step which is thinking by using symbols as the main points (Faiz, 2002)

These three steps are closely related to the understanding step of languages, namely semantic, reflexive and existential or ontological steps (Realistic/ reality). Semantic step is an understanding at the pure level of languages, a higher level of reflexive understanding, approaching to ontological whereas the existential or ontological understanding is understanding at the level of existence of meaning itself. Therefore, Paul Ricoeur asserts that "understanding is basically 'the way of being' (mode of being) or "how to become". However, how can the statement of Paul Ricoeur be accepted because of the understanding only being able to occur at the level of knowledge and how does understanding always get help from knowledge? About the opinions of Paul Ricoeur that "Understanding is a way of being or a way of 'becoming' and not how to know or how to gain knowledge, "Paul Ricoeur just wants to jerk our awareness that hermeneutics is a method that parallels with the method in science. It is meant to treat this hermeneutic method rigidly and structurally as contained in other scientific sciences. Once again, "every word is a symbol" said Paul Ricoeur. Words are full of meanings and hidden intentions. Not only words in literary works but also words inside everyday language are also a symbol because they describe indirect other meanings. There are sometimes figures of speech and all of which can only be understood through these symbols. Therefore, symbols and interpretations are concepts that have a plurality of meanings contained in symbols or words in languages. Every interpretation is an attempt to dismantle the hidden meaning. In the context of literary works, each interpretation is an attempt to unfold the meaning contained in literary works. Therefore, "Hermeneutics aims to eliminate the mystery contained in a symbol by unveiling the unknown and hidden forces inside these symbols", so that "Hermeneutics opens its real meaning, so it can reduce the diversity of meaning from the symbols, "said Paul Ricoeur. Based on Paul Ricoeur's hermeneutic interpretation approach, the function and architectural forms can be considered as independently autonomous texts. According to Ashadi (2016), based on the hermeneutic interpretation approach Paul Ricoeur, the function and form of architecture can be considered as autonomous texts which mean:

- $\quad$ Regardless of the action process carried out

- $\quad$ No longer bound to the founders

- No longer bound by the initial context of the founders

- $\quad$ As a autonomous architectural form

- $\quad$ Apart from the founding process

- $\quad$ No longer bound to the founding figures

- No longer bound to the initial context of its establishment

\section{RESULTS AND DISCUSSION}

Analysis and interpretation activities based on Paul Ricoeur's approach is conducted with the following steps: determine the shape and symbol of the architecture to be analyzed. Analyze and interpret meaning as a message by the intermediary in order to be understood and reach the recipient. The shapes and symbols on the architecture of the traditional house of To-Lotang The categories of symbols or signs on the Towani To-Lotang house are: 


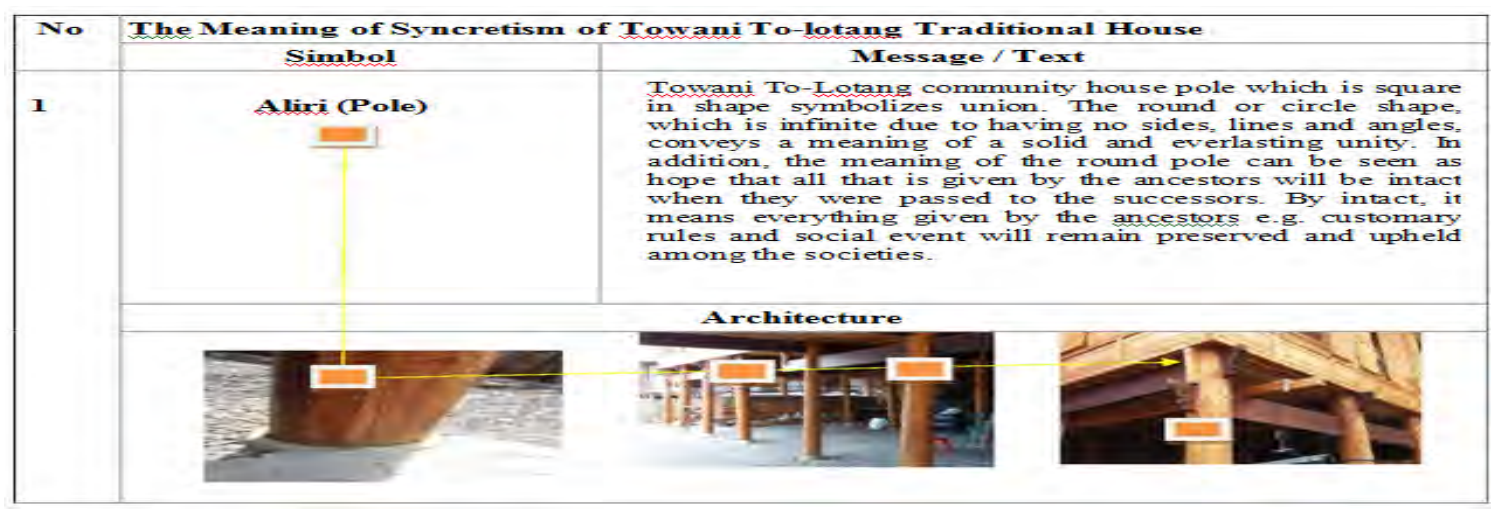

Fig. 2: Aliri (Pole); symbol and message

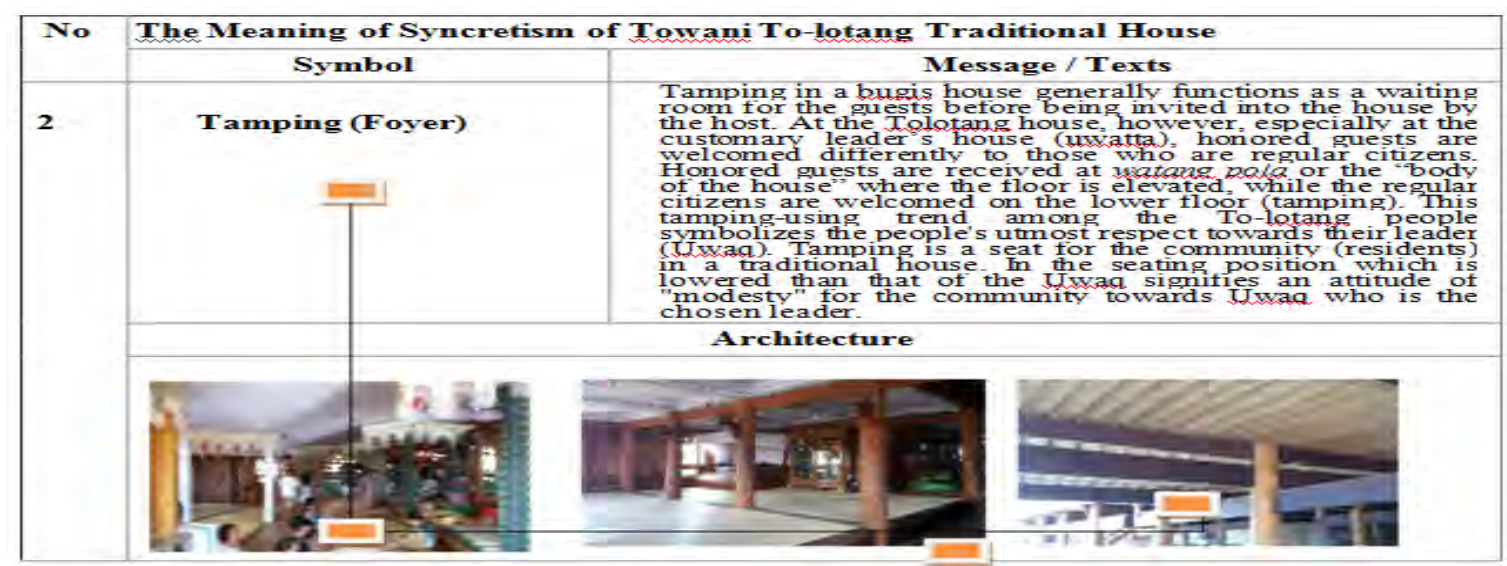

Fig. 3: Tamping (Foyer); symbol and message

\begin{tabular}{|c|c|c|}
\hline \multirow[t]{2}{*}{ No } & \multicolumn{2}{|c|}{ The Meaning of Syncretism of Toxyani To-lotang Traditional House } \\
\hline & Symbol & Message/Text \\
\hline \multirow[t]{3}{*}{3} & Salima (Floor) & $\begin{array}{l}\text { Salima, which is also called Dapara, can have a flat or } \\
\text { uneven shape and is usually made of boards or bamboo- } \\
\text { At the Towani To-totang traditional house, salima is } \\
\text { made of bamboo which has been cut into the desired } \\
\text { size and then arranged and placed transversely on the } \\
\text { floor beam. The bamboo salima in the To-Lotang house } \\
\text { symbolizes unity. }\end{array}$ \\
\hline & & Architecture \\
\hline & & 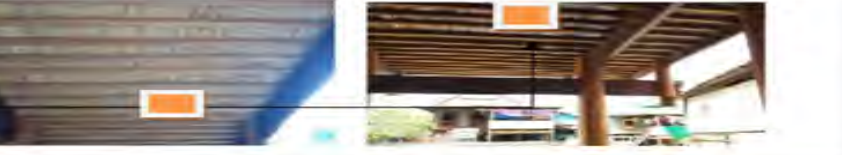 \\
\hline
\end{tabular}

Fig. 4: Ssalima (Floor); symbol and message

- $\quad$ Alliri (pillar)

- $\quad$ Tamping (Porch)
- $\quad$ Salima (Floor)

- $\quad$ Lontang Saliweng (Living Room) 
J. Eng. Applied Sci., 15 (7): 1692-1697, 2020

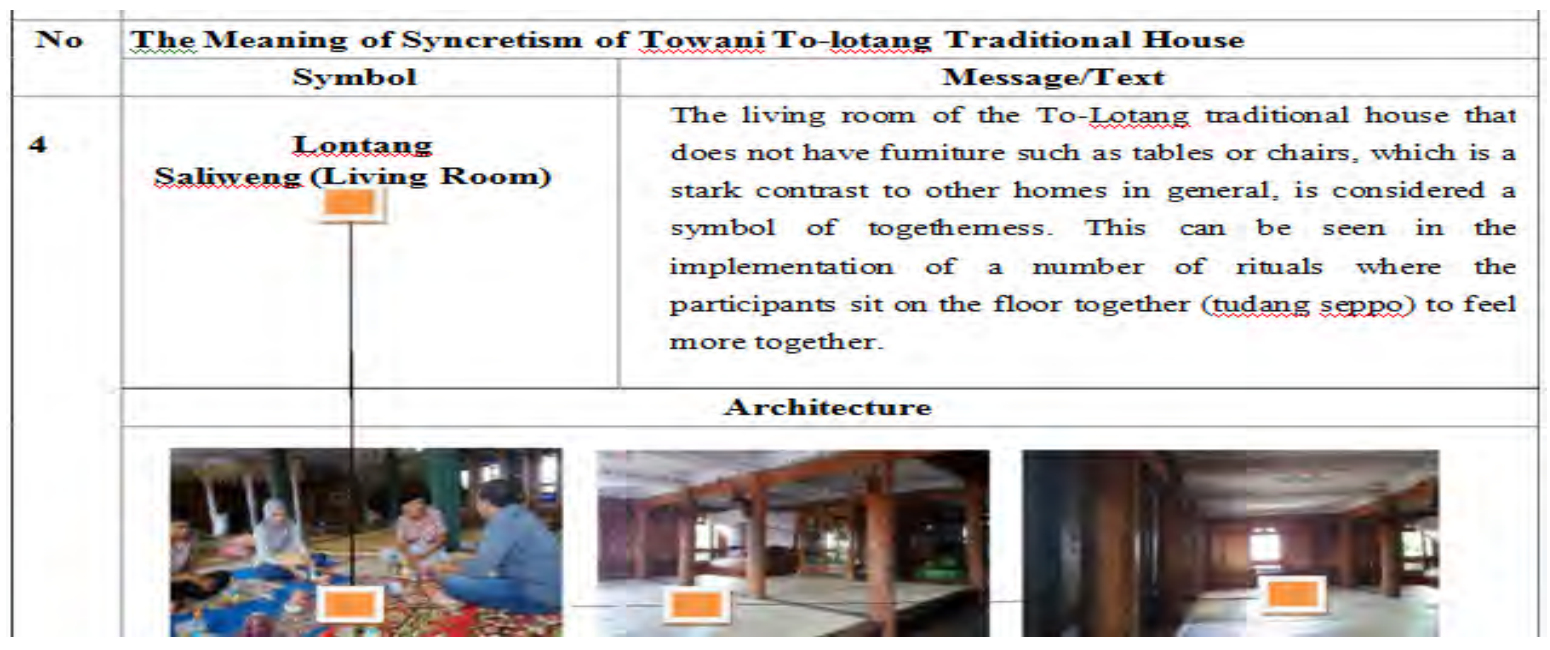

Fig. 5: Lontang Saliweng (Living Room); symbol and message

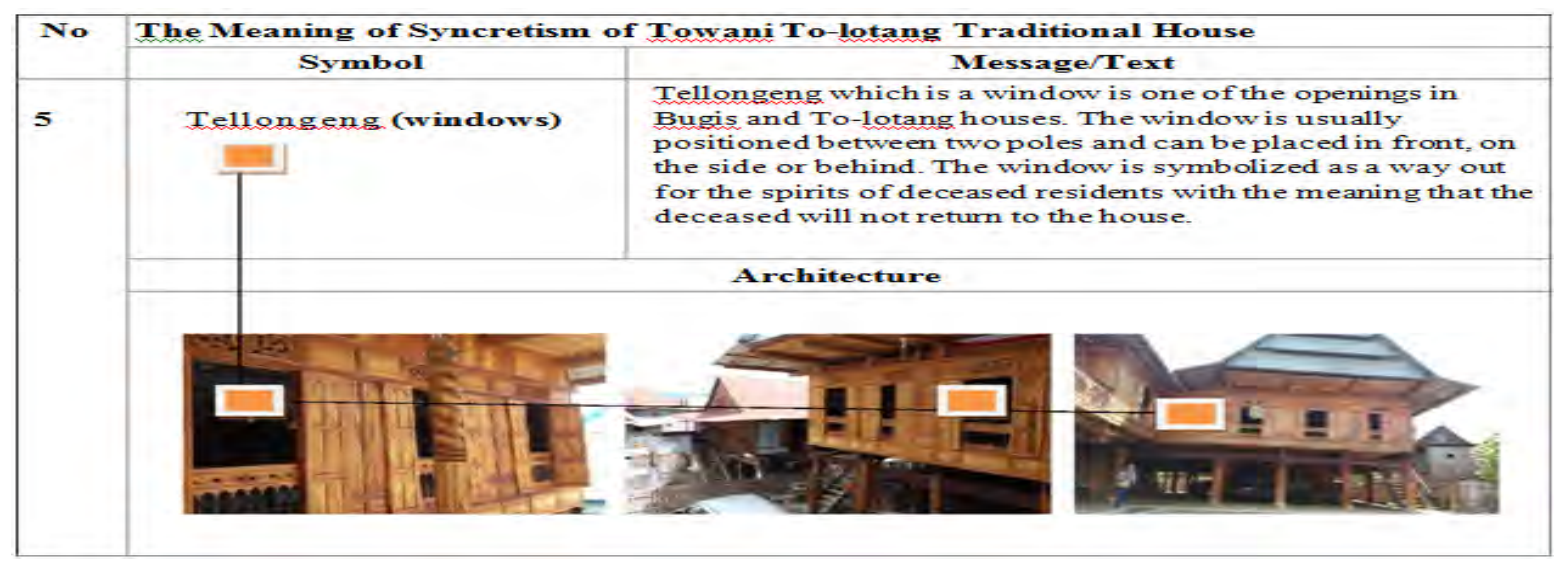

Fig. 6: Tellongeng (Windows); symbol and message

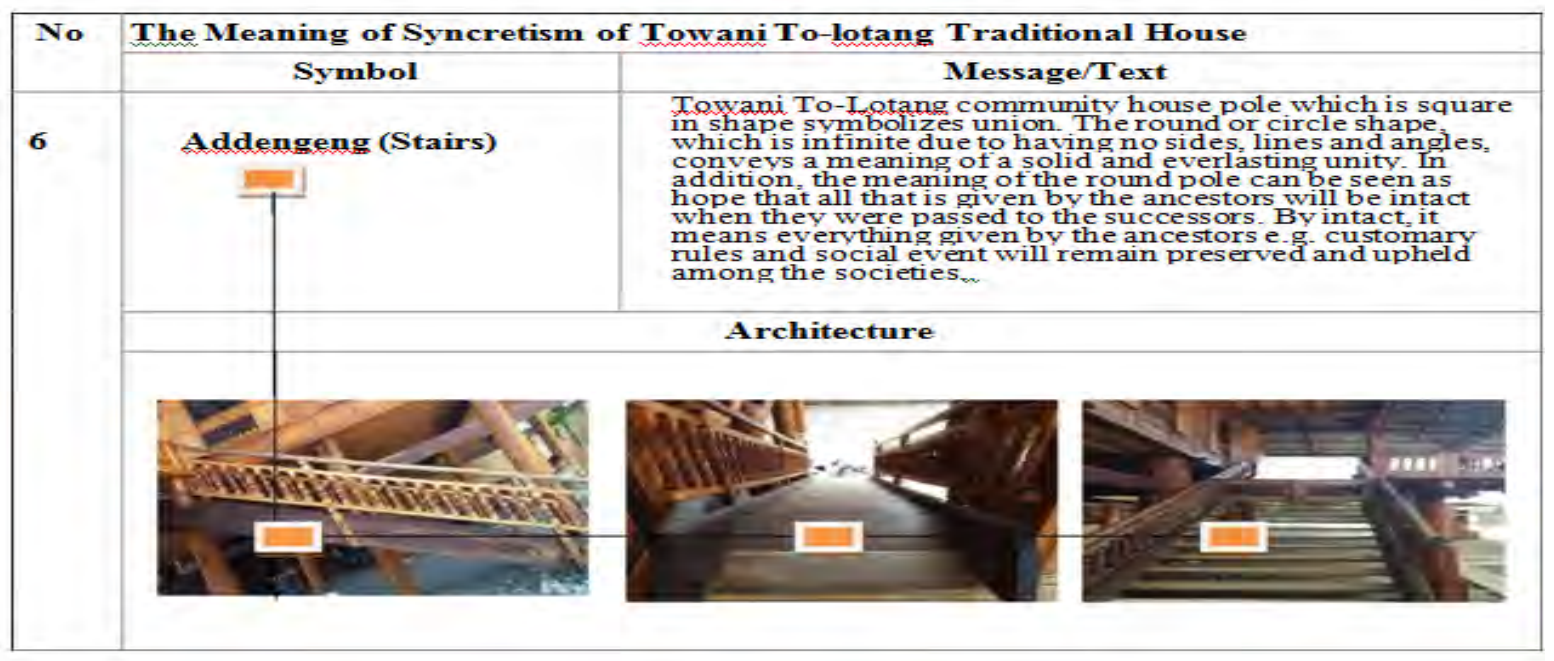

Fig. 7: Addengeng (Stairs); symbol and message 


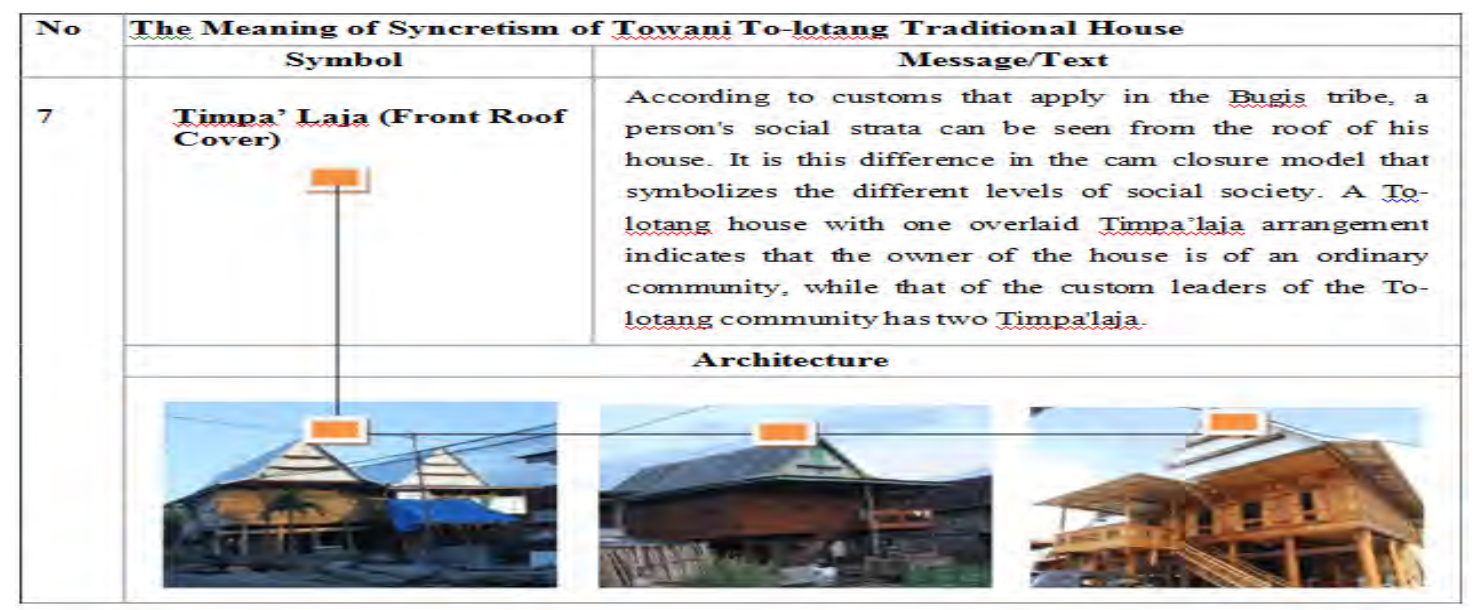

Fig. 8: Timpa’ Laja (Front Roof Cover); symbol and message

- Tellongeng (Windows)

- Timpa' Laja (cover in front part)

- $\quad$ Addengeng (Stairs) Fig. 2-8

Each of the seven symbols or signs above has a meaning or a special message approved by the society of Towani To-Lotang.

\section{CONCLUSION}

The Towani To-Lotang traditional house has seven categories of symbols with their respective messages and meanings agreed upon by the To-Lotang community. The meaning of the seven symbols which we can see at Uwaq's house as a traditional leader is full of values of solidarity in daily life that are highly maintained and respected by the To-Lotang community. The symbols on the To-Lotang community home are messages and hopes of the ancestors to continue to be guarded and conveyed to their successors to this day.

\section{ACKNOWLEDGEMENTS}

The researcher would like to thank the Rector of the Indonesian Muslim University in Makassar and also to Hasanuddin University Makassar for providing facilities and opportunities for conducting research.

\section{REFERENCES}

Ashadi, 2016. [Meaning of Form Synthesis in Architects of the Walisanga mosques]. Ph.D. Thesis, Parahyangan Catholic University, Bandung, Indonesia. (In Javanese)

Faiz, F., 2002. [Hermeneutika Qur'ani: Between Text, Context and Contextualization: Tracing the Hermeneutics of Al-Manar's Tafsir and Al-Azhar's Tafsir]. Qalam, Yogyakarta, Indonesia, ISBN:9789799440143, Pages: 147 (In Indonesian).

Hardiman, F.B., 2005. [The Art of Understanding: Hermeneutics from Schleiermacher to Derrida]. Kanisius, Yogyakarta, Indonesia, Pages: 344 (In Indonesian).

Pelras, C., 2006. [Bugis Man]. Forum Jakarta-Paris, Jakarta, Indonesia, ISBN: 9789799939500, Pages: 449 (In Indonesian).

Ricoeur, P., 1981. Hermeneutics and the Human Sciences: Essays on Language, Action and Interpretation. Cambridge University Press, Cambridge, UK., Pages: 319.

Wachid, A.W.B., 2006. [Hermeneutics as Paul Ricoeur's interpretation system in understanding art texts (In Indonesian)]. Image J. Art Educ., 4: 198-209. 